\title{
India's policy options in middle-east: challenges and opportunities
}

\begin{abstract}
India's relations with Gulf countries and West Asia are very old. The Middle- East region plays a significant role in India's economy, as it provides about two-thirds of India's total oil imports. Bilateral trade, especially with the U.A.E., Iran and other Middle-Eastern countries in the Persian Gulf are growing in recent years. For long times, millions of Indian migrants have been moved to search jobs in the Middle-Eastern Countries and they are considered as a significant part of the total remittance received from out of the country. On the other hand, India always maintains a balancing political strategy with the Middle Eastern countries. As such, the relationship between Israel and Palestine is known as the born enemy. But, India played a separate tactical political strategy with those countries.
\end{abstract}

Volume 5 Issue 3 - 2020

\section{Debasish Nandy}

Associate Professor, Department of Political Science, Kazi Nazrul University, India

\section{Correspondence: Debasish Nandy,Associate Professor, Department of Political Science, Kazi Nazrul University, West Bengal, India, Email debasishnandy.kc@gmail.com}

Received: April 06, 2020 | Published: May 15, 2020

Keywords: Gulf countries, terrorism, Muslim community, neighbours

\section{Introduction}

In the viewpoint of political security, India has signed prisoner repatriation treaties with different Middle-Eastern Countries. India has also signed various agreements with Israel to purchase defence equipment. India has been able to achieve sympathy from MiddleEast countries in the question of border terrorism. West Asia has been witnessed to unforeseen volatile political changes, which have necessitated re-sketching of India's foreign policy in the face of new challenges and opportunities. ${ }^{1}$ The traditional relations aside, India adopted a specific Look West policy in 2005 for deepening her engagement with the West Asian neighbours. West Asian countries have been considered as 'extended 'and 'proximate neighbours'. Stability and democracy are two key factors that India seeks to restore in the region to secure her vital interests that include the safety and security of her expatriates, energy supplies, food security, investments and projects in the region, peaceful uses of nuclear energy, combating maritime security piracy and the sensitiveness of her vast Muslim community. ${ }^{1}$

\section{Reasons behind the growing synergies with the middle-east countries}

There are so many reasons behind India's growing synergies with Middle-east countries which are as follows-

A. Strategically, the Persian Gulf is a very important zone. Considering India's maritime security Strait of Hormuz is very important. It is situated between Persian and Gulf regions.

B. India is very reliant upon Middle East oil and gas and must maintain cordial relations with most of the major suppliers, including Iran, UAE, Qatar, and Saudi Arabia, as well as Iraq. While these states must sell their oil and gas somewhere, and India is a good customer, Delhi does not want to be vulnerable to a temporary cut-off or an increase in prices.

C. Pakistan is very active in Middle-east. Using the platform of OIC and making connections with the particular Arab countries Pakistan is trying to get support on Kashmir issue.
Thus, conducting sophisticated balance-of-power diplomacy, India is trying to counter Pakistani influence in the Gulf region.

D. Israel has been very important to India due to technical, intelligence, and military support. Looking at American continues support to Israel India has been linked with Israel in the post-Cold War period. Now, Israel has been one of the major military equipment providers in India and also an important trading partner.

E. American direct involvement in Middle-east politics is very difficult for India's counter-balance mechanism in Middleeast and also problematic for implementing its autonomous foreign policy in Middle-east. On the one side India's growing synergies with Israel, on the other hand, Israel's contentious attacks on Palestine. This is not only problematic for India in Middle-eastern diplomacy but also for internal politics. India's Muslims hold a soft-corner towards Palestine. To make a balance between Israel and Palestine is a very tuff job for India.

F. New Delhi must consciously calculate the balance between its relations with Tel Aviv and Tehran also. To the USA Iran is a 'rogue state'. The key allegation against Iran is it manufactures illegal nuclear weapons. But, no evidence has in the hand of the USA to date. The USA imposed sanctions on Iran and forced India to discontinue its relations on Iran. Iran is the major fuel supplier courtiers of India, especially natural gas. How should India deal with Iran -this is a very crucial question.

G. Trade with the GCC countries was $\$ 5.5$ billion in 2001, has grown to $\$ 137.7$ billion in 2014-15. However, the trading relations between India and the Middle-eastern states are very impressive. India's energy supply is immensely depending upon the Middle-east.

H. Middle-east has been the hub of international terrorism. The fatal terrorist attacks are conducting by Al Qaida and ISI in Iraq, Syria, Jordon, Yemen and other places. Several numbers of cities have been destroyed and thousands of casualties 
happened by IS in recent times. To combat international terrorism India has taken several steps in collaboration with Arab countries.

\section{India's energy security and middle-east}

India is the seventies country in the world in terms of geographic landmass, and the second-largest in terms of population - with 1.2 billion people. The country enjoys an abundance of traditional and non-traditional energy sources, but these sources are insufficient to meet India's growing needs. It, therefore, resorts to importing most of its energy from abroad, especially, from Middle-East crude oil and natural gas exporters. Meeting the growing demand for energy is a major challenge that is constantly confronting Indian leaders. The country has crude oil imports from around 40\% in 1990 to $70 \%$ in 2011. In 2012, over $64 \%$ of these imports came from the Middle East, a trend that is expected to continue. By 2032, over $91 \%$ of the country's energy needs will be imported. Thus, to secure the best prices and energy security, the country has concluded several number of short- and long-term contracts the government level an, to a lesser extent, through private companies. ${ }^{2}$ Saudi Arabia and Iran are two major sources of India's energy sources. Over the decades, India has been exporting fuel despite many challenges. In the middle of 2004, UPA -I government led by Congress did not link the Iran-India pipeline with the MFN issue, and this resulted in a positive response from Pakistan. ${ }^{3}$

In March 2006, Pakistan, India, and Iran held their first tripartite governmental talks in Tehran. Still, other political factors delayed the project. There was a dilemma to India, whether it would continue its friendly relationship with Iran and continue the process of the tri-national gas pipeline project or not; because during that time India was moving towards the "Civil Nuclear Deal" with the US for mitigating its energy deficiency. Then South Block argued that for adapting the realist foreign policy India was silent about Iran. Then a strong allegation was raised against the Manmohan Singh led UPA -I government whether India's foreign policy will be directed by the USA or its own decision. However, this pipeline Indo-Pak relation might be on a better footing. Although some groups in the US noted that the gas pipeline could advance the India-Pakistan peace process---it could bind the two countries in economic linkages that would be hard to cut off for political reasons (Krepon \& Haider, 2005: 307-20). The Narendra Modi government has also established close relationship with Arab countries to mitigate energy crisis.

\section{Saudi Arabia and India}

After an exchange of visits by the King of Saudi Arabia and the Prime Minister of India in the mid-1950s, there was no high-level visit from India till that of Prime Minister Indira Gandhi in 1982. The King of Saudi Arabia visited India again in January 2006. During his visit, Saudi King Abdullah discussed with Prime Minister Manmohan Singh on various issues. This visit was historic. Saudi Arabia is the key source of Indian crude oil imports. A large number of Indian workers are working in Saudi Arabia. Every year thousands of India Muslim pilgrims visit Saudi Arabia for Haj. Saudi Arabia always plays a key role in Middle-East politics. India and Saudi Arabia jointly set-up a gas-based fertilizer plant in Saudi Arabia. In various sectors, both have agreed to make collaboration like counter-terrorism, education, technology, agriculture, biotechnology, etc.

The momentum for this evolution of the relationship began during Modi's visit to the Kingdom in April 2016. Modi was conferred the highest civilian decoration awarded by King Salman. This recognition was an indication of the importance the Kingdom attaches to its relations with India. The growing bilateral ties were reflected in the announcement of Saudi investments in India worth $\$ 100$ billion. Saudi Arabia also increased India's Hajj quota from 170,000 to 200,000. Saudi Arabia also released the 850 Indian prisoners held in Saudi prisons for minor offenses. New Delhi and Riyadh concluded a strategic partnership agreement in the recent past. Apart from growing economic partnership, both countries have increased multifaceted cooperation and vibrant people-to-people contacts. As a part of the strategic relationship, New Delhi and Riyadh have started to enhance cooperation in defence, maritime security, counterterrorism, science and technology, strategic oil reserves, investments, tourism, and so on. New Delhi looks for Saudi investments in India's petrochemicals, infrastructure, and mining sectors alongside cooperation in economic and security matters. ${ }^{4}$

\section{Indian foreign policy towards Iran}

The development of India's relations with Iran has not followed a constant pattern. It is noteworthy that Iran was one of the first countries with which India signed a Friendship Treaty in March $1950 . .^{5}$ New Delhi-Teheran relations got a setback in mid of the 1950s. Iran had joined some Western military alliances like Bagdad Pact, CENTO, etc. and India was busy with NAM. Iran was very supportive of Pakistan. Radical Islam was flourished during Shah's regime. Pakistan and Iran jointly opposed India's entry into the first OIC summit. After defeating in Bangladesh war Pakistani influence in South Asian politics was deduced. After 1971, Iran's orientation towards India was gradually changing. In 1974, Indian Prime Minister Mrs. Indira Gandhi visited Tehran and Shah of Iran also paid a visit to India. It helped a lot to normalize bilateral relations. However, New Delhi-Tehran relations were derailed once again for three reasons(1) Turbulence in internal politics of India in mid of the 1970s, (2) Iranian revolution in 1979 and (3) Iraq-Iran war.

In between the late 1980s and early the early 1990s due to the following factors Indo-Iran relationship had been strengthened -

A. Iran-Iraq war was ended in 1988. After the war, the end of the war Iran concentrated on the reconstruction of the war-torn economy and development of the economy. On the other hand, India's adoption of a new economic policy just after the Cold War helped to build a relationship with its old friend with a new constructive outlook.

B. In the early stage of the post-Cold-War era, looking to the US hegemony in global politics based on common concerned a close relationship was built between India-China-Iran.

C. Soviet withdrawal from Afghanistan also created new equations in the region in which the two states, Iran and India, developed a similar perception of the evolving situation in Afghanistan. Both saw the rise of the Taliban with concern. It promoted two states to coordinate their policy on the region and in this situation both supported the Northern alliance against the emerging challenge by the rise of the Taliban. ${ }^{6}$

D. After the collapse of the USSR, the Central Asian states have been beneficial for Iran and India.

E. On the issue of energy security, cooperation was enhanced.

F. In the context of the emergence of militancy in Kashmir and Internationalization of the issue, early 1990s India seeks and 
gets the Iranian support to meet certain diplomatic challenges. In this context, India sought Iranian cooperation in dissuading Pakistan from raising Kashmir issue at various world forum.

In the early 1990s, India-Iran relations rejuvenated once again with the visit of Indian Prime Minister Narasimha Rao to Iran in 193. The regular exchange of high-level diplomatic visits helped a lot to establish diplomatic linkage in a new manner. Iran's President Ayatollah Khatami was invited as the Chief Guest for India's Republic Day celebration in 2003. Indian economic reforms led to rapid Industrialization and the emergence of India as the potential fourth largest economic power in the world. As a result of economic growth and growing population, there has been a considerable increase in demand for oil to fuel the land, sea and air transportation. The World Energy Outlook, published by the International Energy Agency (IEA), projects that India's dependence on oil imports would grow to $91.6 \%$ by the year 2020 . While India products only about 25 percent of its total requirement, India imports approximately $70 \%$ of its oil from the Middle East region. ${ }^{8}$ Iran has an adequate reserve of Liquefied Natural Gas (LNG). India concluded a treaty with Iran to import unrestricted import of LNG from Iran. However, in January 2006, this unrestricted import of LNG was restricted due to IAEA's imposition of allegation against Iran for developing nuclear technology. Due to the uncertainty of crude oil and gas supply and the price FactorIndia is facing insecurity in the energy sector. India is very much dependent on its fuel to Middle East countries. After the 9/11 incident Indian perception in energy security has been changed. Because after this incident the USA started to attack Afghanistan and Iraq. India apprehended that the west Asian region and the oil from that region are now more vulnerable than ever in the past.

However, at present the global policy objectives of the new energy policy can be identified as follows:

A. Mobilization of investments for the domestic sector, expansion, and diversification of foreign sources of oil and supplies.

B. Ensuring the existing supplies by consolidating energy ties.

C. Achieving comprehensive energy security through the enhancement of oil and gas exploration and production worldwide by $2020 .^{8}$

\section{Attaining energy independence by 2030 .}

In the early 1990s, India has been interested to strengthen her relationship with Persian Gulf countries particularly Iran. Iran providing $10 \%$ of India's oil at present. ${ }^{10}$ Iran with its geostrategic position sitting astride of Hormuz and large deposits of has plays a crucial role in the Indian Ocean region. India did not conclude any serious strategic partnership with Iran, but it is the neighbour of Pakistan and has a stronghold in the Gulf region. Iran is a key country for India to access into Central Asian region and Pakistan. IndiaIran relations may have complicated progress in New Delhi's recent "Strategic Partnership" with Washington. India's relations with Iran are traditionally positive and in 2003 , the two countries launched a bilateral "strategic partnership" of their own. The supply of the gas is considered through a gas pipeline between Iran-Pakistan-India, there are obstacles in the potential pipeline as it deals. The U.S.A. has vehemently opposed on proposed India-Pakistan-Iran gas pipeline project. India has made a strong relationship with the USA, so it maintaining distance from Iran consciously. Because to USA Iran is an evil state. Some in the U.S. Congress voiced past concerns that New Delhi's policies towards Tehran's controversial nuclear program were not congruent with those of Washington, although these concerns were eased when India voted with the United States at the International Atomic Energy Agency session of September 2005 and February 2006. ${ }^{11}$ India yet recently signed a Liquefied Natural Gas (LNG) deal with Qatar to tide over its energy shortages. Oman is another country with which India has entered into close energy and strategic arrangements in the gulf region. ${ }^{12}$

Due to some technical shortcomings, Iran is not able to produce LNG. Indian firms are also less interested in setup LNG facilities in Iran due to American sanctions on it. However, there is shows light of hope that in mid of 2015, the administration has partly withdrawn its embargo from Iran. Hopefully, India would like to use this opportunity to revitalize the India-Iran oil diplomacy with a new outlook. Once again the USA has imposed sanctions on Iran. Iran remains a reliable source of India's required fuel, especially, LNG. A long back ago India initiated to materialize a gas pipeline project namely 'Iran-PakistanIndia(IPI) Gas Pipeline Project'. Due to the American opposition and unwillingness of Pakistan, this project has not been materialized yet. Chabahar port has established by India and got operated in 2018. It is a great achievement for India. It makes a counterbalance to the Gwadar port of Pakistan. Through Chabahar Port India will be directly connected with Central Asia and Afghanistan.

Indo-Iran ties have been on an upswing in the past few years. Prime Minister Modi visited Tehran in May 2016 with an aim to craft a strategic relationship with Iran and expand India's ties with the West Asia. In February 2018, Rouhani visited India, becoming the first Iranian President to visit India in a decade. During his visit, the two sides signed a dozen agreements. During the visit, India and Iran signed nearly a dozen agreements, centrepiece of which was a deal on development of the strategic Chabahar port. Later, India, Iran and Afghanistan signed a trilateral agreement providing for transport of goods among the three countries through the port. Iran's President Hassan Rouhani requested to Narendra Modi to provide necessary supports to fight coronavirus (Covid-19) in Mid of March, 2020. President Hassan Rouhani, in his letter emphasised that the fight against the coronavirus requires bolstering joint and coordinated regional and international measures, adopting serious strategies, and sustaining huge medical and care costs. Iran is facing tremendous crisis for imposing sanctions by the USA for the last two years. Indian medical team helped a lot to fight against Covid-19. Iran's envoy to the UN also called on the US to lift sanctions on the country and to "depoliticise" its approach toward efforts related to containing the coronavirus outbreak. ${ }^{13}$ The policymakers of the United States saw the growing Indo-Iran relationship negatively. In the post-Cold War era, the Indo-US relationship gradually improved. The strengthening of Indo-US ties began to negatively impact on India's relations with Iran. Therefore, in the wake of the July 2005 launch of a US-India "global partnership' and plans for bilateral civil nuclear cooperation, India began to revisit its Iran policy in favor of closer alignment with the USA. ${ }^{14}$

\section{India's relations with Iraq}

Iraq is an important and controversial Arab state situated in the Persian Gulf region. Iraq diplomatically connected with India in 1947 by the 'Treaty of Perpetual Peace and Friendship'. During the Cold War era, on many occasions, India was not supportive of Iraq. Iraq had joined West-led 'Bagdad Pact'. As India took the non-alignment stand-point that is why India was not happy with Iraq for joining the 
military pact. After 1958, India recognized the new civil government of Iraq, because Iraq disconnected itself from Bagdad Pact. Since the 1960s, Indo-Iraq relations got improved. Iraqi President Saddam Hussein had played a significant role in improving diplomatic relations with India in the 1970s. On several issues, like the Kashmir issue, Saddam Hussain was very much supportive of India. In reply, India had arranged a training programme for Iraqi military personnel in India. Indian experts and professionals had started to work in Iraq, because of its economic potentiality. ${ }^{5}$ To earn "Petro-dollar' Indian workers were also used to go to Iraq to work in oil-fields and construction sectors. Indian companies were also started to invest in Iraq. A notable point is that Iraq was the only secular state in the entire Middle-east. Gradually, both countries started various collaboration within the non-alignment framework. Another factor was favorable for bilateral ties, that is both had been very close to the Soviet Union in the 1970s. Once upon a time, India had planned policy to Iraq-'oil for food', but unfortunately it was not long-lasted. India's Minister of External Affairs, I.K. Gujral visited Iraq during the first Gulf crisis in the 1990s.

President Saddam Hussain always considered India as a friend. Just after the end of the Cold War, during the first Gulf war when the USA had started to attack Iraq then India provided fueling facility to the US military aircraft. Then-Prime Minister of India Chandrashekhar was criticized for taking this decision. It was an anti-standpoint towards an old friend. Just after the first Gulf War ended, the US-led alliance took a resolution in UNO that relations with Iraq will be discarded. The economic sanction was imposed against Iraq. India had vehemently opposed this decision and advocated in favor of Iraq. However, finally, almost all countries had discontinued their relations with Iraq and made Iraq an economically crippled. The basic sources of income in Iraq were fuel export. Despite this, Saddam Hussain was strict in his standpoint, despite the acute economic crisis. India could not take bold decision to continue economic relations with Iraq considering the growing rapprochement with the USA. In May 1998, when India exploded a nuclear bomb at Pokhran of Rajasthan, the entire Western World went against India, but Saddam Hussain supported India. The USA invaded in Iraq in 2003 to tuple the Saddam Husain's regime. India was forced by the USA to send troops to Iraq in 2003. Indian Prime Minister Atal Bihari Vajpayee had denied to send its troop to Iraq. Vajpayee took this decision considering its old friendship with Iraq. India has provided $\$ 20$ million to Iraq for reconstruction. For a decade-long civil war Iraq has been economically crippled country. Some of the Indian private companies are doing business with Kurdistan region of Iraq. However, India has lost its goodwill and hold in Iraq.

\section{India's relations with Oman, UAE, Kuwait and Qatar}

Oman is an important country in the Middle-East. India has historically had close and cordial ties with Oman, geographically the closest country in the Persian Gulf region. As early in March 1953, India signed a treaty with the Sultan of Muscat and Oman (earlier name of Oman. The relations got a boost since the 1970s with the oil boom in the Arab world. India's goods and services based trade with Oman has been gradually increased. A large number of Indian workers are working there. India's foreign remittance is coming from Arab countries. India's companies have invested in various sectors in Middle-eastern countries, especially in Oman. Oman is one of the old diplomatic and trading partners of India with which India concluded a Treaty of Friendship, Commerce and Navigation on May 13,
1953. Since then Indo-Oman friendship has been extended in many ways especially in the field of petroleum goods. Through bilateral reciprocal relationship both have enhanced strategic partnership also. Due to Oman's strategic location, India may use it in a multipurpose direction. Due to Oman's strategic location at the straits of Dormouse and its proximity to the Bab-el- Mandeb, both are willing to cooperate concerning Gulf security and maritime security near the Somalia coast. Both countries are increasing their joint air and naval exercises. ${ }^{15}$

United Arab Emirates (UAE) is a very good partner of India. India's workers are working in UAE. In August, 2019, Prime Minister Narendra Modi was honoured with the 'Order of Zayed', the UAE's highest civilian award, on Saturday as a mark of appreciation for his efforts to boost bilateral ties between the two nations. The award has earlier been bestowed on several world leaders, including Russian President Vladimir Putin, Queen Elizabeth II and Chinese President Xi Jinping." The award in the name of Sheikh Zayed bin Sultan Al Nahyan, the founding father of the UAE. Indians are the most favored workers among other countries due to their discipline, hard-working nature, honesty and non-involvement in internal politics and local crime. After the economic growth in India in the early 1990s. the trend to go 'Dubai Cholo' or destination Dubai has been a little bit of change. Other reasons are very alarming for Indian workers. Some workers are being persecuted in Middle-eastern countries and also been physically assaulted. They are being paid low wages. Some children and women are being trafficked and selling-out in different Arab countries. A big recede is involved in these illegal and inhuman activities. The government of India has negotiated with Arab states over the issue. India's IT companies, oil companies, and Hotel companies have invested a lot in Middle-east companies. India has opened-up Consulate Offices and Embassies in Arab countries. Indian major cities are well-connected with UAE, Kuwait, and Qatar.

Qatar holds the 9th largest reserves in OPEC and the 13th largest in the world. Qatar's crude oil production ranks 17th in the world, with most of the country's production sent abroad as exports. Kuwait has been a reliable and fourth-largest supplier of crude oil to India. During 2014-15, Kuwait was the fourth-largest oil supplier to India after Saudi Arabia, Iraq and Venezuela and it meets about $10 \%$ of India's energy needs. Total bilateral trade with Kuwait during 2014-15 was US\$ 14.58 billion (Rs.88, 843.72core). India's imports from Kuwait during 2014-15 were US\$13.38billion of which POL accounted for US\$ 12.28 billion (Crude oil import was worth US\$ 11.47 billion). The reduction in Kuwait's exports to India, compared to 2013-14, was due to the sharp fall in crude oil price in the last two quarters of 201415 and reduced purchase of crude oil from Kuwait by Indian oil PSUs. In Rupee terms, the total imports from Kuwait were at 81,510.69 cores during 2014-15 (Source: Embassy of India, Kuwait, November 2015, Report).

\section{India's relational equations with Israel and Palestine factor}

India's relations with Israel are a very complex one. Primarily, Indo-Israel bilateral relations were not friendly. India did not recognize Israel as a sovereign state. Both Gandhi and Nehru were against the creation of a Jewish state in the Arab world. Mahatma Gandhi had unequivocally opposed the creation of a Jewish state in an Arab homeland, although they had their sympathy for Jews suffering under Nazi atrocity. Gandhi also believed in conspiracy theories built on 'Zionist-British-American collaboration. ${ }^{16}$ According to Nehru 
"we refrained because of our desire not to offend the sentiments of our friends in Arab countries" ${ }^{17}$ However, throughout the entire Cold War period, Indo-Israel relations were not significantly improved. Since its inception, Israel is pampered by the USA. Due to New Delhi's relational complexity with Washington, New Delhi-Tel Aviv relations remained unfriendly. Many times, Israel wanted to provide technological support to India, but India denied accepting. In 1967, Israel gave a proposal to India that it wants to develop the wastelands of Rajasthan for mitigating irrigating and drinking water problems. India refused the Israeli proposal. In 1967, during the Arab-Israel War leading Indian newspapers like Times of India, Indian Express, The Statesman, and The Hindustan were very critical about India's support to Arab countries. However, Israel's continuous attacks on Palestine were criticized by the Indian government. In the early 1990s, IndoIsrael relations started with a lot of expectations. In 1992, Prime Minister Narasimha Rao decided to establish diplomatic, economic, defence and technological linkages with Israel. With a short span, New Delhi-Tel Aviv relations have gained momentum. Within a few years, India emerged as the three second-largest trading partner of Israel after Hong Kong and also Israel became the largest supplier of military equipment after Russia.

A. Narasimha Rao to Atal Bihari Vajpayee and Manmohan Singh to Narendra Modi all Prime Ministers of India gave priority in enhancing bilateral relations with Israel. Modi paid a visit to Israel in September 2017 for fostering bilateral technological and defence relationship. The end of the Cold War has changed the relational equation between India and Israel. Due to the increase of India's closeness with the USA, India-Israel relations gradually developed.

B. India ranked the world fifth-largest military spender with a budget of $\$ 53.5$ billion for 2017 F.Y. India's security is highly threatened by Pakistan and China. Thus, India is strengthening its military capability by purchasing modern equipment from Israel. Israel is one of the best defence equipment manufacturer countries in the world.

C. With the establishment of diplomatic relations in 1992 the economic relationship has been enhanced. The market economy led to enhance bilateral relations.

D. To combat international terrorism New Delhi-Tel Aviv came together.

E. To get technological support India has leaned towards Israel.

India particularly appreciated Israel's willingness to supply military equipment and ammunition during the Kargil operations in 1999 and Operation Parakram in 2002. There is also useful mutually beneficial cooperation in the intelligence domain. ${ }^{5}$ Both countries have made cooperation in space science also. The Zionist Lobby of the USA plays a vital role in shaping the Israel policy towards India. However, the UPA government had indeed tried to maintain a balance in maintaining the relationship with Israel and Palestine, but the NDA is more pro-Israeli. In August 2012, two countries signed an $\mathrm{MoU}$ for conducting collaborative research. Bilateral trade has increased gradually in the post-Cold War era. In 1992, the bilateral trade volume was less than $\$ 200$ million and it reaches $\$ 6.6$ billion in 2011-2012. The diamond business between the two countries is very impressive in volume. Israel is now a strong defence partner of India and a reliable friend also. India's growing market is very lucrative for Israel. In 2014, more than 100 tons of olives were produced in
Rajasthan, India also benefited from Israel in agricultural technology to increase agricultural products. Israel is cooperating with India in water conservation, solar power, missile technology, etc.

\section{India's response to democratic uprising in the Arab World}

Unquestionably, the Arab World has witnesses' acute democratic crises. Most of the Arab countries have had an experienced either rigid monarchical system or military regime or autocracy. In 2011, democratic upsurge in the Arab World started in Tunisia and passed through Egypt, Libya, and Yemen. In Syria, bitter fighting is still going on between Assad's troops and opposition forces. Being the world's largest democracy India has moral support to the pro-democratic movement initiated by Arab countries during the 'Arab Spring'. In August 2012 at the 16th Summit of the Non-Alignment Movement at Tehran, Prime Minister Manmohan Singh said," The deteriorating situation in Syria is a matter of particular concern." However, the policy of the government of India towards democratic upsurge in the Arab World was severely criticized. India's role was nothing but a mute spectator.

\section{India and organization of Islamic conference (OIC)}

India's relations with OIC have witnessed many ups and downs. The role of OIC is very important to establish India's diplomatic and economic relations with Arab countries. This organization was established in 1969 to establish Islamic solidarity among Islamic countries across the globe. India's trade with Middle-east countries, fuel import and diplomatic support in world politics are significantly dependent upon OIC. Now OIC has 56 members. Being the world's largest Muslim populated country India is also to make a bridge based on religious sentiment. As an observer country, India participated in its first conference at Rabat, Morocco. Pakistan has opposed India's involvement in OIC. From the beginning, India received an offer to be an observer of OIC and also to be a member of OIC. The second option is not viable for India. If India accepts the second option, then it will have to follow the resolutions of OIC. It is very tuff for a secular country. On March 1, 2019, the 46th OIC meeting was held at Abu Dhabi. India's External Affairs Minister Sushma Swaraj was invited to address in inauguration as a 'guest of honor'. It was a Historical moment for OIC and India also as a non-Islamic country's representative inaugurated the meeting of OIC. It implied India's growing reputation in Middle-East.

Pakistan's adamant stands toward India's non-entry in the grouping. In addition to this, the OIC's stand on the Kashmir issue questions the state of Jammu and Kashmir as a legitimate part of India. The organization has been generally supportive of Pakistan's concerns over Jammu and Kashmir. After passing CAA in the Indian Parliament many OIC members vehemently India and they are very supportive of Pakistan's arguments. West Asia and India's growing economic and energy interdependence makes it difficult for the former to ignore the latter. However, India and OIC members discussing on some priority areas like peace and security, terrorism, inter-faith harmony, poverty alleviation, food security, and women empowerment

(https://thediplomat.com/2019/03/india/).

\section{India and gulf cooperation (GCC)}

India's relations with GCC members are very close. Over the years, GCC countries are meeting India's energy crisis needs. The reciprocal relationship is based on mutual respect and trust. Indeed, GCC has been 
a collective entity for India which is tremendously significant only not for the energy sector but various purposes. It is true that Gulf countries are not India's "immediate" neighbours but also indispensable "Far neighbours" who have already been indispensable to India's "looks West policy". GCC countries are separated from India by the Arabian Sea. But, at the same time, it is also connecting the sea line for India and GCC countries. India has been considered an inevitable stake in the stability, security and economic well-being of the Gulf. India is moving first towards the GCC states for further economic, strategic and cultural and security issues. In 2018, the Dubai government and the Indian Embassy to Dubai had jointly celebrated "Dewali" to enhance cultural relations. In recent years, the GCC has emerged as one of the major trading partners of India.

The first GCC-India Industrial Conference was held in Mumbai in February 2004. India had signed an agreement with GCC which is known as the Framework Agreement. The basic objective of this agreement was to enhance economic cooperation between the two sides. Two rounds of talks for finalizing aspects like tariff rules, rules of origin, etc. have been held. In the political sphere bilateral engagement has also manifested in different manners. Diplomatically, India has been close to GCC through rounds of political dialogues. ${ }^{18}$ Indian strategic interest has been reflected by the political dialogues. Both sides recognized the significance of this dialogue, which marked "a new era" in India- GCC relationship. The very first dialogue focused on topical issues like Iraq, Middle-East, terrorism, UN reforms, multilateralism, NAM and OIC. The economic potentialities of GCC members and India's projection as an emerging global economic and political power have brought both sides in a common platform based on the convergence of basic national interests. India already started to invest in GCC countries. Several initiatives have taken by both sides. The GCC's substantial oil and gas reserves are of vital importance for India's energy needs. Indian professionals have held a very good position in GCC countries. Presently around 6 million Indians are working on different developmental projects in GCC countries. The Indian "work-force" is playing a very vital role in GCC countries. Historically, India had cordial relations with GCC countries. That is why India is trying to rejuvenate the shape of the relationship through the lens of history approximately 6 million Indian workers in the region, are of vital interest to India. India's economic linkages with the GCC have increased steadily especially due to growth in oil imports. During 2011-12, India's exports to GCC were USD 45.36 billion. The bilateral two-way trade during the period was USD 145.72 billion, marking a $24.13 \%$ increase over the previous year, and is growing at a steady pace. ${ }^{19}$

\section{Islamic state of Iraq and Syria (ISI) and India's security challenge}

After the death of Osama Bin Laden in 2011 in Pakistan, it was thought that the days of religious extremism may be eliminated from the world. But, al Qaida supreme had a strong follower group. It was realized after the rapid emergence of ISI. This group has been renaming from time to time. The roots of ISIS trace back to 2004 when the organization is known as "al Qaeda in Iraq" formed. Abu Musab al-Zarqawi, who was originally part of al Qaeda Network, founded this militant group. In 2010, Masri died in a US-Iraqi operation and Abu Bakr al-Baghdadi holds power. Baghdadi died in October 2019. In 2014, ISIS took control of Falluja, Mosul, and Tikrit in Iraq, and declared itself a caliphate, which is a political and religious territory ruled by a leader known as a caliph. ISIS was very much active in Iraq, Syria, Jordon, Afghanistan, and Yemen. Within a very short span IS had gained enormous power and build-up worldwide network. This organization considered much more power than al-Qaida. It had started to run the parallel economy by capturing the oil fields of Iraq and Syria. The security forces of these two countries were unable to control the unimpeded destructive activities of IS. After 2015 this organization had projected a new world map, which was a projection of the future occupied territory of IS. The leaders and Ideologues of this organization started to propagate that within a few years the entire world will come under IS. The entire world will be ruled by IS based on sharia law. This organization has a strong network in South Asia. Through the spreading of jihadi ideology and using social media and websites, ISI used to provoke the youths to join IS. ${ }^{19-24}$

\section{Conclusion}

The Persian Gulf countries are the major fuel supplier of India. This region plays a significant role in India's economy. To make a balance with India's far Western neighbors, especially Persian Gulf countries South Block has planned to make a balance with 'Act East Policy' with its 'Middle-east policy. A new policy has been coined by Modi government-'Link West' through which multi-layered connectivity is to be built. The rapid developmental activities were taking place in GCC states during this period. Thousands of laborers from India went to these states to work in oil fields and various projects. Currently, more than 6 million Indian nationals are working in GCC countries and they are sending approximately $\$ 40$ billion US dollars to India. For various reasons, India should develop its close diplomatic linkages with this region, especially, to Qatar, Kuwait, Oman, Iran, Iraq, Saudi Arabia, UAE, etc.

\section{Acknowledgments}

None.

\section{Funding}

None.

\section{Conflicts of interest}

Author declares that there is no conflict of interest.

\section{References}

1. Chakraborty Sukalpa. India's Look West Policy and the Syrian Conundrum. World Focus. 2013.

2. Khan Z-u-I. India's Middle-East Energy Strategy. Aljazeera Centre for Studies. 2013.

3. Mahalingam S. Politics of the Iran-Pakistan-India Gas Pipeline Project. In: IP Khosla, editor. Energy and Diplomacy, Konark, New Delhi Mahmood; 2005

4. Ningthoujam Alvite. India-Saudi Arabia Ties: Scaling New Heights: Prime Minister Modi's latest trip to Riyadh underscores a growing relationship. The Diplomat. 2019.

5. Sikri Rajiv. Challenge and Strategy: Rethinking India's Foreign Policy. New Delhi: Sage; 2009.

6. India, Iran, China Cooperation. The Hindustan Times. 1993.

7. Baba Noor Ahmed. Contextualizing the Indo-Iranian Relations. World Focus. 2013. 
8. Vallabu Srilatha. Energy Security and India's Foreign Policy. Ocean Digest. 2008;145(23):1.

9. Prabhakar, Akhilesh Chandra. India's Foreign Security of Supply and the Gulf. India Quarterly. 2003;59(1-2).

10. Tanvi Madan. Energy Security Series. India. The Brooking Foreign Policy Studies. Brookings Institution; 2006.

11. K Alan Kronstadt. India-U.S. Relations. USA: CRS Report for Congress; 2007.

12. Dennis and Chaturvedi. Energy security and the Indian Ocean Region New Delhi: South Asian Publishers Pvt. Ltd; 2005.

13. Mohan Geeta. Iran President writes to PM Modi for assistance to fight Covid-19. India Today. 2020.

14. Baruah Amit. Partnership with Iran in Trouble. Hindu. 2006.

15. Nandy Debasish. Energy Security and Economic Growth in South Asia: An Alternative Policy Option. In: Ramesh Chandra Das, editor Handbook of Research on Economic and Political Implications of Green Trading and Energy Use. USA; IGI Global, Hershey PA; 2019.

16. Bhattacharya Joyati. India and Israel: Friends yet Not. World Focus. 2013.
17. Parthasarathy G. Jawaharlal Nehru, Letters to Chief Ministers 19471964. New Delhi: Oxford University Press for the Jawaharlal Nehru Memorial Trust; 1986.

18. Nandy Debasish. Gulf Cooperation Council: Investigating its Role in Regional and Global Milieu. In: Debasish Nandy, Biswanath Chakraborty, editors. The Role of International Organization in Global Politics. Ahmedabad: Blue Roan Publishing; 2019.

19. Mawali, Nasser Al. Intra-Gulf Cooperation Council: Saudi Arabia Effect. Journal of Economic Integration. 2015;30(3)

20. Diplomatic Moves on to get more Oil and Gas. ORF Energy News Monitor. 2005;1(31):19-25.

21. Krepon M, Haider Z. A Pipeline for Peace? The Indian Express. 2005.

22. Muni SD, Pant Girish. India's Energy Security: Prospects for Cooperation with Extended Neighborhood. Rupa Co. New Delhi. 2005.

23. Patnaik Ajay. Framing Indo-Central Asian Relations, 1990s-2000s. In: Marlene Lauelle, Sebastien Peyrouse, editor. Mapping Central Asia: Indian Perceptions and Strategies. 1984.

24. Sharma RR. India and Emerging Asia. New Delhi: Sage Publications; 2005. 